\title{
Strategi Promosi Pengembangan Pariwisata Di Kabupaten Bima Di Tinjau Dari Perspektif Ekonomi Syariah
}

\author{
Muhammad Rasyad Al Fajar ${ }^{1 *}$, Ifantri ${ }^{2}$ \\ ${ }^{1,2)}$ Institut Agama Islam Muhammadiyah Bima \\ *Corresponding Author: rasyad1010@gmail.com
}

\begin{abstract}
ABSTRAK - Penelitian ini menggunakan metode kualitatatif dan bersifat deskriptif analisis. Sumber data yang digunakan adalah data primer dan data sekunder. Dengan menggunakan metode pengumpulan data yaitu observasi, wawancara, dan dokumentasi. Hasil yang diperoleh dari penelitian ini yaitu Dinas Pariwisata Kabupaten Bima merumuskan langkah-langkah strategi promotion mix yaitu periklanan, penjualan perorangan, publisitas, promosi penjualan, dan pemasaran sporships. Dalam strategi promosi Dinas Pariwisata Kabupaten Bima menggunakan media elektronik seperti internet sudah berjalan dengan baik. Dinas Pariwisata Kabupaten Bima juga mempunyai Instagram dan Facebook sendiri. Akan tetapi strategi promosi melalui media cetak masih belum maksimal dilakukan. Strategi promosi Dinas Pariwisata Kabupaten Bima dalam perspektif ekonomi syariah dapat disimpulkan bahwa berdasarkan prinsip ekonomi Islam dalam berpromosi dan etika bisnis Islam yang terdiri dari kejujuran, amanah, keadilan, dan istiqomah. Dinas Pariwisata sudah menjalankan prinsip Islam dengan benar sesuai dengan syariat Islam.
\end{abstract}

Kata Kunci - Strategi; Promosi; Perspektif Ekonomi Syariah

ABSTRACT - The research objective was conducted to determine how the tourism promotion strategy used by the Bima Regency Tourism Office in increasing tourist visits and views from the perspective of the Islamic economy. This research uses a qualitative method and is descriptive analysis. The data sources used are primary data and secondary data. By using data collection methods, namely observation, interviews, and documentation. The results obtained from this study are the Bima Regency Tourism Office formulating the promotional mix strategy steps, namely advertising, personal selling, publicity, sales promotion, and marketing of sporships. In the promotion strategy of the Bima Regency Tourism Office using electronic media such as the internet has been going well. Bima Regency Tourism Office also has its own Instagram and Facebook. However, the promotion strategy through print media is still not maximized. The promotion strategy of the Bima Regency Tourism Office in a sharia economic perspective can be concluded that based on Islamic economic principles in promotion and Islamic business ethics which consist of honesty, trustworthiness, justice, and istiqomah. The Tourism Office has implemented Islamic principles properly in accordance with Islamic law.

Keywords - Strategy; Promotion; Islamic Economic Perspective

\section{PENDAHULUAN}

Upaya mengembangkan objek dan daya tarik wisata serta kegiatan promosi dan pemasaranya, baik di dalam maupun di luar negeri terus ditingkatkan secara terencana, terarah, terpadu dan efektif, antara lain dengan memanfaatkan secara optimal kerjasama kepariwisataan regional dan global guna meningkatkan hubungan antar bangsa. ${ }^{1}$

Sektor pariwisata saat ini telah menjadi aspek penting dalam kemajuan ekonomi suatu Negara. Pariwisata menjadi pilihan utama dalam pengembangan wilayah. Perkembangan pariwisata telah mengalami banyak perubahan baik perubahan pola, bentuk dan sifat kegiatan perjalan destinasi wisata, dan lain-lain. Pembangunan suatu daerah dapat membuka daya tarik wisata baru bagi para wisatawan, baik wisatawan asing maupun lokal. Potensi pariwisata di Nusa Tenggara Barat (NTB) yang amat sangat melimpah dapat mengangkat ekonomi Daerah apabila setiap objeknya dikelola dengan baik oleh pemerintah maupun 
pihak-pihak disekitar obyek wisata tersebut sehingga banyaknya kunjungan wisatawan akan berpengaruh pada naikya devisa Negara. Dalam hal ini peran strategi promosi untuk perencanaan pariwisata sangat dibutuhkan, perencanaan pariwisata menjadi penting karena fenomena pariwisata semakin kompleks, pariwisata semakin kompetitif dan promosi pariwisata semakin gencar dilakukan tidak hanya di Nusa Tenggara Barat (NTB) tetapi juga di Daerah lain. Pariwisata mempengaruhi semua orang dalam komunitas tertentu, semua yang terlibat dalam pariwisata perlu berpartisipasi dalam proses perencanaan pariwisata agar pariwisata di NTB khususnya Kabupaten Bima dapat bersaing dengan Daerahdaerah lain.

Kabupaten Bima merupakan salah satu dari beberapa daerah yang menjadi daerah destinasi wisata di Provinsi Nusa Tenggara Barat (NTB) yang memiliki banyak obyek wisata yang perlu dikembangkan atau dijadikan sebagai peluang dalam meningkatkan baik Pendapatan Asli Daerah (PAD) maupun pendapatan masyarakat disetiap obyek wisata masing-masing. Kabupaten Bima mememiliki beberapa kawasan yang berpotensi untuk dikembangkan menjadi daerah obyek tujuan wisata karena didukung topografi tinggi berbukit dan daerah rendah dekat dengan pantai yang diarahkan sebagai kawasan pendukung pariwisata. Terdapat 106 obyek wisata di Kabupaten Bima yang dikelola oleh pemerintah maupun dikelola secara mandiri (swasta).

Dibawah ini merupakan data jumlah obyek Pariwisata Kabupaten Bima tahun 2017.2

Daftar Objek Daerah Tujuan Wisata Di Kabupaten Bima

\begin{tabular}{|r|l|l|c|}
\hline \multicolumn{1}{|c|}{ No } & $\begin{array}{l}\text { Destination Zone } \\
\text { (Zona Tujuan) }\end{array}$ & $\begin{array}{c}\text { Area Coverage } \\
\text { (Cakupan Area) }\end{array}$ & $\begin{array}{c}\text { Number of } \\
\text { Attractions }\end{array}$ \\
\hline 11 & $\begin{array}{l}\text { Around Lingkar } \\
\text { Tambora Zone }\end{array}$ & $\begin{array}{l}\text { District Of Sanggar and } \\
\text { Tambora }\end{array}$ & 18 \\
\hline 22 & $\begin{array}{l}\text { Around Donggo } \\
\text { Zone }\end{array}$ & $\begin{array}{l}\text { District Of Madapangga- } \\
\text { Bolo-Donggo dan soromandi }\end{array}$ & 12 \\
\hline 33 & $\begin{array}{l}\text { Around Langgudu } \\
\text { Bay Zone }\end{array}$ & $\begin{array}{l}\text { District Of Parado, Monta, } \\
\text { Dan Langgudu }\end{array}$ & 14 \\
\hline 44 & $\begin{array}{l}\text { Around Lewamori } \\
\text { Zone }\end{array}$ & $\begin{array}{l}\text { District Of Woha, Belo, } \\
\text { Palibelo Dan Lambitu }\end{array}$ & 15 \\
\hline 55 & $\begin{array}{l}\text { Salawa Zone (Sape- } \\
\text { Lambu-Wawo) }\end{array}$ & $\begin{array}{l}\text { District Of Sape-Lambu Dan } \\
\text { Wawo }\end{array}$ & 36 \\
\hline 66 & $\begin{array}{l}\text { Around Sangiang } \\
\text { Api Zone }\end{array}$ & $\begin{array}{l}\text { District Of Wera Dan } \\
\text { Ambalawi }\end{array}$ & 11 \\
\hline & \multicolumn{2}{|l}{ Jumlah } & $\mathbf{1 0 6}$ \\
\hline
\end{tabular}

Sumber : Dinas Pariwisata Kabupaten Bima Dalam Buku Panduan Wisata Kabupaten Bima Tahun 2018

Peranan pemasaran pariwisata dapat meningkatkan pengetahuan dan kesadaran pemangku kepentingan pariwisata, terutama pangsa pasar utama terhadap upaya pelestarian produk-produk wisata secara berkelanjutan. Strategi pemasaran menyediakan kerangka koordinasi, sehingga para pemangku kepentingan pariwisata yakni Dinas Pariwisata (DISPAR) Kabupaten Bima yang bertanggung jawab terhadap obyek-obyek wisata akan memiliki arah yang sama dalam upaya pengembangan mengelola destinasi dan mempromosikan pariwisata di daerahnya.

2 Dinas Pariwisata Kabupaten Bima, Travel Guide To Bima Regency (Panduan Wisata Kabupaten Bima), (Jakarta, ASITA 2018), 16,17. 
Berikut hasil kunjungan wisatawan baik wisatawan domestik maupun mancanegara yang terdata di Dinas Pariwisata Kabupaten Bima sebagai berikut:

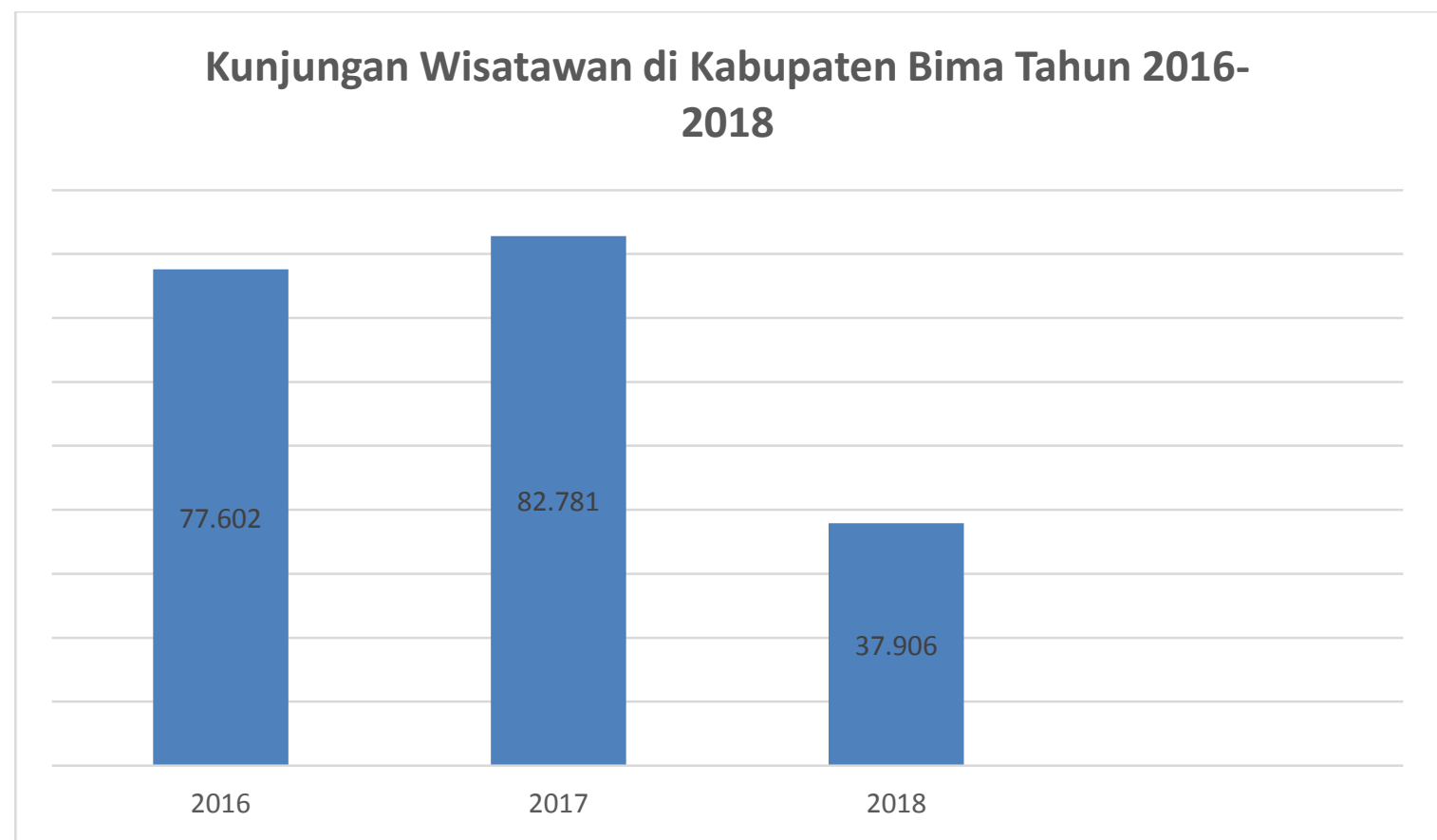

Sumber: Dinas Pariwisata Kabupaten Bima Dalam Buku Panduan Wisata Kabupaten BimaTahun 2018

Strategi pemasaran di tingkat destinasi seharusnya lebih diperkuat untuk mengidentifikasi target-target pasar destinasi pariwisata yang bersangkutan serta strategi promosi dan branding yang tepat bagi target-target pasar yang dituju. Dalam hal ini strategi promosi diharapkan mampu membantu pariwisata Kabupaten Bima untuk lebih dikenal tidak hanya oleh masarakat Kabupaten Bima saja, tetapi juga masyarakat luar dan diharapkan mampu bersaing dengan pariwisata di daerah lain. Dalam pengembangan daya tarik wisata, diperlukan dukungan promosi dan publikasi yang baik apalagi pada era global seperti sekarang ini publikasi dapat dilakukan dengan mudah melalui internet. Pemerintah daerah diharapkan mampu merencanakan pembangunan pariwisata hingga memasarkan obyek wisata yang ada khususnya di Kabupaten Bima, karena kurangnya pembaruan informasi mengenai kepariwisataan di daerah ini dibutuhkan strategi promosi yang baik agar visi dan misi pariwisata daerah dapat terwujud.

Undang-undang Nomor 10 Tahun 2009 tentang Kepariwisataan Pasal 5 butir a menyebutkan, "Kepariwisataan diselenggarakan dengan prinsip menjunjung tinggi norma agama dan nilai budaya sebagai pengejewantahan dari konsep hidup dalam keseimbangan hubungan antara manusia dan Tuhan Yang Maha Esa, hubungan antara manusia dan sesama manusia, dan hubungan antara manusia dan lingkungan". Berdasarkan pasal ini maka kebijakan dan pengembangan pariwisata di Indonesia khususnya Kabupaten Bima harus didasarkan pada nilai-nilai agama dan adat istiadat setempat. ${ }^{3}$ Hal ini juga disebabkan oleh negara Indonesia yang mayoritas agama Islam terbanyak maka, dalam mengembangkan kepariwisataan khususnya wisata syariah, Kemenparekraf menggandeng beberapa pihak yakni Dewan Syariah Nasional (DSN), Majelis Ulama Indonesia (MUI) dan Lembaga Sertifikasi Usaha (LSU), untuk menyusun pedoman-pedoman tentang kepariwisataan syariah di Tanah Air.

3 Abdurahman Misno, "Analisi Praktik Pariwisata Syariah Perspektif Hukum Ekonomi Islam”, Jurnal Ekonomi dan Bisnis Islam, (Universitas Ibn Khaldum Bogor), 136. 
Al-Qur'an Surat Shaad ayat 24 memberikan gambaran bahwa pada prinsipnya pemasaran adalah jenis muamalah yang masuk dalam urusan keduniaan yang diperbolehkan Nabi Muhammad Saw. Allah SWT, dan Rasul-Nya telah menetapkan pertukaran barang dengan persetujuan dan ijin orang tersebut.

\section{LANDASAN TEORI}

\section{Pengertian Promosi}

Promosi merupakan salah satu variabel dalam bauran pemasaran yang sangat penting dilaksanakan oleh perusahaan dalam memasarkan produk jasa. ${ }^{4}$ Agar proposi berjalan efektif, perusahaan harus menyusun strategi dalam memasarkan produknya. Ada beberapa pengertian promosi sebagai berikut:

Menurut Danang Sunyoto promosi merupakan salah satu variabel dalam bauran pemasaran yang sangat penting dilaksanakan oleh perusahaan dalam memasarkan produk. Kegiatan promosi bukan saja berfungsi sebagai alat komunikasi antara perusahaan dengan konsumen,melainkan juga sebagai alat untuk mempengaruhi konsumen dalam kegiatan pembelian atau penggunaan produk sesuai dengan kebutuhan dan keinginanya. ${ }^{5}$

Promosi merupakan kegiatan mendiseminasikan brand image dari suatu produk/jasa dengan berbagai metode yang dapat menjangkau target pasar sehingga konsumen termotivasi untuk mencoba dan membelinya. ${ }^{6}$

\section{Fungsi Promosi}

Terence A. Shimp menyatakan bahwa promosi memiliki lima fungsi yang sangat penting bagi suatu perusahaan/lembaga. Kelima fungsi tersebut dijabarkan sebagai berikut: ${ }^{7}$

1. Informing (Memberikan Informasi)

Promosi membuat konsumen sadar akan produk-produk baru, mendidik mereka berbagai fitur dan manfaat merek, serta memfasilitasi penciptaan citra sebuah perusahaan yang menghasilkan produk atau jasa. Proosi menampilkan peran informasi bernilai lainya, baik untuk merek yang diiklankan maupun konsumenya, dengan mengajarkan manfaat-manfaat baru dari merek yang telah ada.

2. Persuading (Membujuk)

Media promosi atau iklan yang baik akan mampu mempersuai peanggang utuk mencoba prduk dan jasa yan ditawarkan. Terkadang persuai berbentuk mempengaruhi permintaan prime, yani menciptakan permintaan bai keseluruhan kategoi produk. Lebih sering, promosi berupaya untuk membangun permintaan sekunde, permintaan bagi merek perusahaan yang spesifik.

3. Reminding (mengingatkan)

Iklan menjaga agar merek perusahaan tetap segar dalam ingatan para konsumen. Saat kebutuhan muncul, yang berhubungan dengan produk dan jasa yang di iklankan, dampak promosi di masa lalu memungkinkan merek pengiklan hadir di benak konsomen. Periklanan lebih jauh didemostrasikan

4 Widiya Agustina, "Analisis Strategi Promosi Dan Pelayanan Pariwisata Guna Meningkatkan Jumlah Pengunjung Di Pantai Sari Ringgung Pesawaran Dalama Perspektif Etika Bisnis Islam ("Skripsi”, Bandar Lampung 17 Mei 2018), 24.

5 Ibid, 25 2019), 20

6 Rimsky K. Judisseno, Brending Destinasi dan Promosi Pariwisata (PT Gramedia Pustaka Utama, Jakarta

7 Warnadi, Aris Triyono, Manajemen Pemasaran, (Yogyakarta, CV BUDI UTAMA Mei 2019), 86. 
untuk mempengaruhi pengalihan merek dengan mengingatkan para konsumen dan akhir-akhir ini belum membeli merek yang tersedia dan mengandung atribut-atribut yang menguntunkan.

4. Adding Value (menambah nilai)

Terdapat tiga cara mendasar di mana peruasahaan memberi nilai tambah bagi penawaran-penawaran mereka,inovasi, penyempurnaan kualitas, atau mengubah persepsi konsumen. Ketiga komponen nilai tambah tersebut benarbenar independen. Promosi yang efektif menyebabkan merek di pandang lebih elegan, lebih bergaya, lebih bergengsi, dan bisa lebih unggul dari tawaran pesaing.

5. Assisting (mendampingi upaya-upaya lain dari perusahaan)

Periklanan merupakan salah satu alat promosi. Promosi membantu pewakilan penjualan. Iklan mengawasi proses penjualan produk-produk perusahaan dan memberikan pendahuluan yang bernilai bagi wiraniaga sebelum melakukan kontak personal dengan para pelanggan yang prospektif. Upaya, waktu, dan biaya periklanan dapat di hemat karena lebih sedikit waktu yang diperlkan untuk memberikan informasi kepada prospek tentang keistimewaan dan keunggulan produk jasa. Terlebih lagi, iklan melegitimasi atau membuaat apa yang dinyatakan klaim oleh perwakilan penjual lebih kredibel. Jika fungsi diatas ditujukan lebih kepada konsumen, maka sebenarnya funsi promosi juga memiliki tujuan untuk memenangkan persaingan dengan kompetitor. Salah satu strategi memenangkan persaingan dalam dunia pemasaran atau promosi adalah menggunakan public relations dengan baik. ${ }^{8}$

\section{Strategi Promosi}

Bauran promosi merupakan gabungan dari berbagai jenis promosi yang ada untuk suatu produk yang sama agar hasil dari kegiatan promo yang dilakukan dapat memberikan hasil yang maksimal. Sebelum melakukan promosi sebaiknya dilakukan perencanaan matang yang mencakup bauran promosi

Wiliam J. Staton menyatakan sebagaimana yang dikutip oleh Djaslim Saladin, bahwa bauran promosi mempunyai pengertian yaitu "Bauran promosi adalah kombinasi dari penjualan tatap muka, periklanan, promosi penjualan, publisitas, dan hubungan masyarakat yang membantu pencapaian tujuan perusahaan". ${ }^{9}$

Adapun aneka macam melakukan promosi, dan kecendrunganya iyalah cara yang dipakai makin berkembang, secara garis besar kelompok cara promosi dapat dibagi menjadi sebagai berikut: periklanan (Advertising), personal seling, publisitas, sales promotion.

1. Periklanan (Advertising)

Periklanan merupakan salah satu bentuk kegiatan promosi yang sering dilakukan perusahaan melalui komunikasi non individu dengan jumlah biaya seperti iklan melalui media masa, perusahaan iklan, lembaga non laba, individu-individu yang membuat poster dan sebagainya. Periklanan dilakukan untuk memasarkan produk baru atau tidak terjangkau salesmen atau personal

8 Ibid, 88.

9 Andi Nur Azakiyah, "Strategi Promosi Dinas Kebudayaan Dan Pariwisata Dalam Meningkatkan Kunjungan Wisatawan Di Pantai Tanjung Bira Kecamatan Bontobahari Kabupaten Bulukumba", ("Skripsi", UIN Alaudin Makassar, 2013), 15. 
selling. Periklanan sering dilakukan melalui surat kabar, majalah, radio, dan TV, pos langsung ataupun bahkan melalui biro periklanan. ${ }^{10}$

Periklanan merupakan salah satu bentuk dari komunikasi inpersonal (impersonal communication) yang digunakan oleh perusahaan barang atau jasa. Kegiatan periklanan berarti kegiatan menyebarluaskan berita (informasi) kepada pasar (masyarakat/konsumen). Masyarakat perlu diberitahu siapa (sponsor) yang bertindak melalui media iklan tersebut. Dalam hal ini pihak sponsor membayar kepada media yang membawakan berita itu. Kgiatan periklanan adalah suatu alat untuk membuka komunikasi dua arah antara penjual dan pembeli, sehingga keinginan mereka dapat terpenuhi dalam cara yang efisien dan efektif, dalam hal ini komunikasi dapat menunjukan cara-cara untuk merngadakan pertukaran yang saling memuaskan.

Iklan adalah satu alat yang digunakan dalam memperkenalkan suatu produkatau jasa kepada publik atau menyebarluaskan informasi dengan menggunakan media masa, seperti pertelevisian, radio, majalah dan surat kabar.

2. Penjualan Perorangan (Personal Selling)

Personal Selling adalah kegiatan promosi yang dilakukan antara individu yang sering bertemu muka yang ditunjukan untuk menciptakan, memperbaiki, menguasai atau mempertahankan hubungan pertukaran yang saling menguntungkan kepada bela pihak. ${ }^{11}$

Personal selling atau penjual pribadi disini adalah merupakan komunikasi persuasiv seseorang secara individual kepada seseorang atau lebih calon pembeli dengan maksud menimbulkan permintaan (penjualan). Dalam operasinya, personal selling lebih fleksibel dibandingkan dengan orang lain. Ini disebabkan karena tenaga-tenaga penjual tersebut dapat secara langsung mengetahui keinginan, motif dan perilaku konsomen, dan sekaligus dapat melihat reaksi konsumen sehingga mereka langsung dapat langsung mengadakan penyesuaian seperlunya.

3. Publisitas (Publicity)

Publisitas merupakan kegiatan promosi yang hampir sama dengan periklanan yaitu melalui media masa tetapi informasi yang di beritakan tidak dalam bentuk iklan tetapi berupa berita. ${ }^{12}$ Sejumlah informasi tentang seseorang, barang atau organisasi / perusahaan yang di sebarluaskan ke masyarakat dengan cara membuat berita yang membuat arti komersial atau berupa penyajian-penyajian yang lain yang bersifat positif. Dengan demikian suatu perusahaan beserta produknya dapat menjadi perhatian umum.

Untuk melakukan publisitas tidak perlu membayar, disinilah letak perbedaan atara publisitas dengan periklanan, dalam hal ini mana periklanan memerlukan sejumlah pembayaran.

4. Promosi Penjualan (Sales Promotion)

Alat kegiatan promosi selain periklanan, personal selling dan publisitas ialah berupa sales promotion yang dilakukan dengan peragaan, pertunjukan dan pameran, demonstrasi dan berbagai macam usaha penjualan yang tidak bersifat rutin.

5. Pemasaran Sponsorships (Marketing Sponsorships)

10 Daryanto, Manajemen Pemasaran, (Bandung, PT Sarana Tutorial Nuraini Sejahtera, 2011), 95.

11 Rambat Lupiyoadi, A. Hamdani, Manajemen Pemasaran Jasa, (Jakarta, Salemba Empat, 2009), 123

12 Daryanto, Manajemen Pemasaran...........,96 
Pemasaran sponsorships adalah aplikasi dalam mempromosikan perusahaan atau lembaga/instansi atau salah satu merek dengan kegiatan tertentu. Sponsorshisp memiliki kemampuan untuk menyampaikan di sejumlah bidang komunikasi. Paket sponsorship yang dikemas secara tepat dapat menciptakan atau memperkuat kesadaran akan nama yang tinggi. Melakukan sponsorship pada suatu even menawarkan peluang yang sangat baik bagi pelanggan dan staf. Satu hari menyelenggarakan lomba atau kegiatan sejenis bisa menjadi katalisator yang bermanfaat untuk membangun hubungan atau motifasi karyawan.

\section{Tujuan Promosi}

Rossiter dan Percy mengklisifikasikan tujuan promosi sebagai efek dari kounikasi sebagai berikut: ${ }^{13}$

1. Menumbuhkan persepsi pelanggan terhadap suatu kebutuhan (category need).

2. Memperkenalkan dan memberikan pemahaman tentang suatu produk kepada konsumen (brand awareness).

3. Mendorong pemilihan terhadap suatu produk (brand attitude).

4. Membujuk pelanggan untuk membeli suatu produk (brand purschase itention).

5. Membagi kelemahan unsur bauran pemasaran lain (purschase facilitation)

6. Menanamkan citra produk dan perusahaan (positioning).

\section{Pengertian Pariwisata}

Menurut undang-undang nomor 10 tahun 2009 tentang kepariwisataan, yang di maksud dengan pariwisata adalah berbagai macam kegiatan wisata dan didukung berbagai fasilitas dan layanan yang disediakan oleh masyarakat, penguasa, pemerintah, dan pemerintah daerah. Sedangkan Hunzieker dan Krapf menyatakan bahwa pariwisata dapat didefinisikan sebagai keseluruhan jaringan dan gejala-gejala yanhg berkaitan dengan tinggalnya orang asing disuatu tempat, dengan syarat bahwa mereka tidak tinggal disitu untuk melakukan suatu pekerjaan yang penting yang memberikan keuntungan yang bersifat permanen maupun sementara. ${ }^{14}$

\section{Komponen Dasar Pariwisata}

Sedangkan menurut Gunn dalam Suryadana dan Octavia komponen dasar pariwisata, yaitu:

1. Atraksi/daya tarik wisata yang dikategorikan dalam:

a. Sumber daya alam meliputi: air mancur, kolam, dan sungai.

b. Sumber daya dan budaya, meliputi arkeologi, sejarah, hiburan, olahraga, kesehata, keagamaan, dan perdagangan.

2. Akomodasi, tempat makan dan minum, tempat belanja, aksebilitas.

3. Transportasi udara, air, dan darat.

4. Air bersih, pembuangan limbah, keamanan, listrik dan pemadam kebakaran.

\section{Jenis-Jenis Wisata}

Jenis-jenis wisata atau kegiatan pariwisata berdasarkan jenis-jenisnya dapat dikelompokan ke dalam 14 kategori yaitu wisata budaya, wisata kesehatan, wisata

\footnotetext{
13 Warnadi, Aris Triyono, Manajemen Pemesaran............,89.

14 Suryadana, M Lingga dan Vani Octavia, Pengantar Pemasaran Pariwisata, (Bandung: Alfabeta 2015),30
} 
olah raga, wisata komersial wisata industri, wisata politik wisata, konfensi wisata sosial, wisata pertanian, wisata maritim (marina) atau bahari wisata, wisata cagar alam, wisata untuk buru, wisata pilgrim ${ }^{15}$

\section{Promosi dalam Perspektif Islam}

Ekonomi Islam juga merupakan promosi yang dilakukan untuk menawarkan, menginformasikan, menjual produk atau jasa di pasar. Karena dengan promosi masyarakat akan mengetahui keberadaan produk atau jasa. Prinsip yang digunakan Nabi Muhammad SAW, adalah personal selling, iklan, promosi penjualan dan humas (hubungan masyarakat). namun cara-cara yang ditetapkan oleh Nabi Muhammad SAW berbeda dengan promosi yang dilakukan pada saat ini. Cara yang dilakukan Nabi Muhammad SAW tidak terlepas dari nilai-nilai moralitas. Promosi pada era Nabi belum berkembang sepeti sekarang ini, dimana seluruh produsen telah menggunakan alat modern, media internet, televisi, radio dan lain-lain. Dalam istilah manajemen sifat dari Nabi dapat diterjemahkan sebagai supel, cerdas, deskripsi tugas, delegasi wewenang, kerja tim, cepat tanggap, kordinasi, kendali dan supervise. Bauran promosi merupakan kombinasi dari alatalat promosi, yaitu periklanan, penjualan tatap muka (personal selling), promosi penjualan publisitas yang dirancang untuk menjual barang dan jasa. Untuk menjual barang dan jasa secara langsung kita telah melakukan kegiatan bisnis. ${ }^{16}$

Dalam konsep Al-Qur'an tentang bisnis juga sangat komperehensif, parameter yang dipakai juga tidak menyangkut dunia saja, namun juga menyangkut urusan akhirat. Al-Qur'an memandang kehidupan manusia sebagai proses yang berkelanjutan. Manusia harus bekerja bukan hanya untuk meraih sukses di dunia namun juga kesuksesan di akhirat. ${ }^{17}$

Menurut Madjid Fakhri etika yang harus dilakukan dalam berpromosi sesuai dengan anjuran Islam iyalah jangan pernah mengobral sumpah, dalam beriklan maupun berpromosi, jujur, menjaga agar selalu memenuhi akad dan janji, menghindari berpromosi palsu. ${ }^{18}$

\section{Pariwisata Dalam Perspektif Ekonomi Syariah}

Wisata sebagai salah satu kebutuhan manusia telah diatur dalam syariat Islam, sehingga dalam pelaksanaanya haruslah didasarkan pada nilai-nilai Islam. Tujuan syariat Islam atau yang dikenal dengan istilah maqashid syariah diantaranya adalah Imam Al-Ghazali dan Imam Al-Zurjawi, keduanya sangat memperhatikan bagaimana Islam sangat memperhatikan kebutuhan manusia dan apa yang bermanfaat untuk mereka. ${ }^{19}$

Manusia membutuhkan suasana baru yang akan menyegarkan jiwa dan raganya, suasana yang berbeda dengan keadaan sehari-harinya yang menjadikanya kembali bersemangat dalam melakukan aktifitas. Wisata saat ini tidak hanya menjadi kebutuhan sekunder namun menjadi kebutuhan primer pada beberapa kalangan.

15 Pemerintah Daerah Kabupaten Bima, Pariwisata dan Ekonomi Kreatif, Penguatan Industri Pariwisata Daerah Melalui Ekonomi Kreatif,(Bima Maret 2019) , 11-13.

16 Ahmad Mustag, The Furture Of Economics: An Islamic Perspektif, (Jakarta: Asy Syaamil Press \& Grafika), 2001), 25.

17 Ibid, 25.

18 Ali Hasan, Marketing dan Bnk Syariah, (Bogor, Ghalia Indonesia, 2010), 25-26.

19 Abdurahman Misno, "Analisis prasktik Pariwisata Sayari'ah Perspektif Hukum Ekonomi Syari'ah, Jurnal Ekomi Bisnis Islam........,146. 
Aktifitas pariwisata dalam pandangan Islam tidak bisa dilepaskan dari tiga pilar utama, yaitu Iman, Islam, dan Ihsan. Ketiga pilar ini sekaligus menjadi penyangga dan pijakan dari seluruh aktifitas pariwisata. Dengan demikian, aktifitas pariwisata dalam Islam sarat dengan nilai-nilai (tangible) keimanan, ketauhidan, dan ketaqwaan kepada sang Khalik, Allah SWT, yang telah menciptakan segala bentuk keindahan, baik yang ada di darat, laut, maupun udara. Seala bentuk keindahan tersebut merupakan karunia Allah untuk hamba-Nya yang harus disyukuri dan ditafakuri. 20

Sementara itu, dalam kaitanya dengan nilai-nilai ideal dari kepariwisataan bagi Islam adalah bagaimana umatnya mengambil I'tibar atau pelajaran dari hasil pengamatan dalam perjalanan yang dilakukan sebagai di isyaratkan dalam AlQur'an Q.S Saba' ayat 18 :

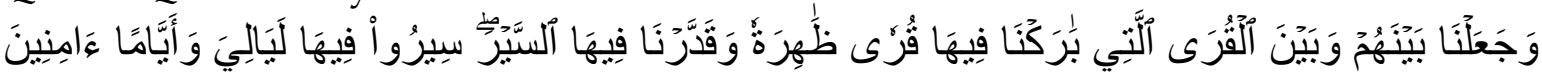

Terjemahan: Dan Kami jadikan antara mereka dan antara negeri-negeri yang Kami limpahkan berkat kepadanya, beberapa negeri yang berdekatan dan Kami tetapkan antara negeri-negeri itu (jarak-jarak) perjalanan. Berjalanlah kamu di kota-kota itu pada malam hari dan siang hari dengan dengan aman..$^{21}$

Menurut ayat diatas, perjalanan manusia dengan maksud dan keperluan tertentu di permukaan bumi harus dengan kehati-hatian. Islam pada dasarnya membahas masalah hubungan terhadap tiga pokok; Tuhan, alam, dan manusiaatau teologi, kosmologi, antropologi. Oleh karena itu, agama yang meliputi segala hal atau kaffah, memberikan pertimbangan terhadap aktivitas hidup dunia modrn yang tidak bisa terlepas dari tiga hal pokok tadi, termasuk dunia kepariwisataan. Dunia kepariwisataan termasuk subsistem kehidupan yang merupakan salah satu aspek dari muamalah, atau kehidupan sosial kemasyarakatan, ekonomi dan budaya. Keindahan rasa dekat dengan Allah SWT. sang maha segala-galanya dan kebahagiaan dunia dan akhirat merupakan harapan setiap insan. ${ }^{22}$

Pariwisata dalam tradisi Islam dimulai dari kemunculan Islam sebagai agama universal, yaitu ketika dikenal konsep ziyarah, yang secara harfiyah artinya berkunjung. Selanjutnya lahir konsep dhiyah, yaitu tata krama berkunjung yang mengatur etika dan tata krama serta hukum hubungan sosial antara tamu (dhaif) dengan tuan rumah (mudhif). Konsep ziyarah tersebutpun mengalami perkembangan dan melahirkan berbagai bentuk. Ziayarah yang dapat diartikan sebagai pariwisata atau tour dalam Islam, mengenal juga berbagai terminologi, seperti assafar, arrihlah, intisyar dan istilah-istilah lain yang seakar denganya.

Pariwisata syariah sebagai term baru dalam ranah pariwisata di indonesia muncul sebagai efek dari kesadaran umat Islam akan layanan pariwisata yang didasarkan kepada nilai-nilai kepercayaan masyarakat di indonesia yaitu islam. Perkembangan ekonomi Islam yang terus berjalan merabah kebidang Islamic Tourisme atau pariwisata syariah.

Peluang dari pengembangan wisata syari'ah (Islami) yaitu potensi pasar baik wisatawan domestik (penduduk indonesia 90\% beragama Islam) maupun mancanegara (khusus timur tengah dan malaysia cukup menjajikan). Potensi yang menjajikan terhadap pengembangan wisata Islami atau wisata syari'ah pada

20 Juhjaya S. Praja, Ekonomi Syariah, (CV. Pustaka Setia, Bandung, 2012), 133.

21 Q.S Saba' 34:18

22 Mustafa Edwin Nasution dkk, Pengenalan Ekslusif Ekonomi Islam, (Jakarta: Kencana, 2007), 115. 
tanggal 30 Oktober 2013 pada acara Indonesia Halal Expo (INDEX) di Jakarta Internasional Expo yang didukung oleh Kementerian Pariwisata dan Ekonomi Kreatif (Kemenparaekraf) dan Majelis Ulama Indonesia.

Peraturan perundang-undangan yang berkaitan dengan pariwisata syariah adalah:

1. Peraturan Menteri Pariwisata Republik Indonesia Nomor 1 Tahun 2016 Tentang Penyelenggaraan Sertifikasi Usaha Pariwisata.

2. Peraturan Menteri Pariwisata dan Ekonomi Kreatif Indonesia No. 2 Tahun 2014 Tentang Pedoman Penyelenggaraan Usaha Hotel Syariah.

3. Peraturan Gubernur Nusa Tenggara Barat No. 51 Tahun 2015 Tentang Wisata Halal.

Majelis Ulama Indonesia (MUI) mendorong pemerintah untuk membentuk Undang-Undang Pariwisata Syariah sebagai dasar hukum pengaturan dan pengembangan pariwisata di Tanah Air. Masukan tersebut dikeluarkan MUI setelah melalui Ijtima Ulama Komisi Fatwa se-Indonesia V Tahun 2015. Komisi B2 Musail Fiqhiyyah Muashirah (masalah fiqih kontemporer) tentang usul pembentukan perundang-undangan. Menurut MUI, penerbitan aturan itu agar perkembangan wisata di Tanah Air tetap menjaga nilai-nilai dan ajaran agama.

Adapun MUI menyebutkan beberapa hal yang harus diperhatikan dalam pembentukan peraturan pariwisata syariah, seperti berorentasi pada kemaslahatan umum; berorentasi pencerahan, penyegaran, dan ketenangan; menghindari kemusyrikan dan khurafat; menghindari maksiat, seperti zina, pornografi, pornoaksi,prostitusi, minuman keras, narkoba dan judi.

Hal lain yang diperhatikan, yakni menjaga perilaku, etika dan nilai luhur kemanusian seperti menghindari perilaku hedonis dan asusila; menjaga amanah, keamanan dan kenyamanan; bersifat unifersal dan inklusif; menjaga kelestarian lingkungan; terakhir, menghormati nilai-nilai luhur sosial budaya dan kearifan lokal. 23

\section{METODE PENELITIAN}

Penelitian ini mengarah pada pendekatan kualitatif deskriptif. Alasanya adalah pertama. Menyesuaikan metode kualitatif lebih mudah apabila berhadapan dengan kenyataan jamak. Kedua, metode ini menyajikan secara langsung hakikat hubungan antar peneliti dengan responden. Ketiga, metode ini lebih peka dan lebih dapat menyesuaikan diri dengan banyak penajaman pengaruh bersama terhadap pola-pola nilai yang dihadapi. ${ }^{24}$

Dalam penelitian ini peneliti menggambarkan tentang strategi promosi pengembangan yang dilakukan oleh Dinas Pariwisata Kabupaten Bima dalam perspektif ekonomi syariah.

Penelitian ini berlokasi di Kantor Dinas Pariwisata Kabupaten Bima yang bertempat di bekas Pandopo lama Jln. Lintas Bima-Sape Kecamatan Rasanae Timur Kelurahan Raba Dompu Kota Bima, yang mana sebagai penanggung jawab utama yang akan mengembangkan dan mengelola seluruh objek destinasi wisata yang berada di Kabupaten Bima.

23 Abdurahman Misno, Alisis Praktik Pariwisata Syariah Perspektif Hukum Ekonomi Syariah,.........,149-150

${ }^{24}$ Lexy J Moleong, metodologi penelitian kualitatif, (Bandung PT. Remaja Rosdakarya, 1989), 9-10 


\section{HASIL PENELITIAN}

\section{Strategi Promosi Pariwisata yang Dilakukan Dinas Pariwisata Kabupaten Bima}

Kabupaten Bima memiliki berbagai objek wisata yang menarik untuk dikunjungi yaitu terdiri dari wisata alam, wisata budaya, wisata buatan dan wisata religi. Wisata di Kabupaten Bima yang sangat beragam ini perlu untung dikembangkan dan harus memiliki strategi khusus untuk mempromosikanya. Inilah salah satu alasan mengapa Kabupaten Bima menarik untuk dikunjungi.

Adapun aneka macam melakukan promosi, dan kecendrunganya iyalah cara yang dipakai makin berkembang, secara garis besar kelompok cara promosi dapat dibagi menjadi sebagai berikut: periklanan (advertising), personal seling, publisitas, dan seles promotion.

\section{Periklanan (Advertising)}

Bapak Selamet selaku Kasi Ekonomi Kreatif Berbasis Seni, Budaya, Media, Desain dan IPTEK juga mengatakan bahwa media promosi yang digunakan oleh Dinas Pariwisata Kabupaten Bima yaitu sebagai berikut: ${ }^{25}$

a. Media cetak

Media cetak yang digunakan adalah menerbitkan brosur booklet dan bukubuku wisata yang disajikan di area publik.

b. Media elektronik

Media elektronik yang digunakan adalah internet yang memuat informasi seputar Kabupaten Bima. Informasi ini bisa melalui Google, Facebok, Instagram dll.

Menurut Daryanto menyatakah bahwa periklanan merupakan salah satu bentuk kegiatan promosi yang sering di lakukan perusahaan melalui komunikasi non individu dengan jumlah biaya seperti iklan melalui media masa, perusahaan iklan, lembaga non laba, individu-individu yang membuat poster dan sebagainya. Periklanan di lakukan untuk memasarkan produk baru atau tidak terjangkau salesmen atau personal seling. Periklanan sering dilakukan melalui surat kabar, radio, dan $\mathrm{Tv}$, post langsung ataupun bahkan melaui biro periklanan. ${ }^{26}$

2. Penjualan perorangan (personal selling)

Personal selling adalah kegiatan promosi yang dilakukan antara individu yang sering bertemu muka yang ditunjukan untuk menciptakan, memperbaiki, menguasai atau mempertahankan hubungan pertukaran yang saling menguntungkan kepada bela pihak.

Bapak Julkifli selaku kasi pemberdayaan masyarakat bidang pengembangan pariwisata Kabupaten Bima menyatakan bahwa:

“Dinas Pariwisata Kabupaten Bima melakukan penyuluhan dan pelatihan kepada Kelompok-kelompok Sadar Wisata (POKDARWIS) di tiap-tiap Kecamatan yang memiliki spot wisata, dan pelaku usaha kreatif untuk memasarkan berbagai destinasi wisata Kabupaten Bima dan sekitarnya serta produk UMKM seperti baju kaos Cinderamata, batik Bima, kopi Kabupaten Bima dan Sarung khas Kabupaten Bima. Kabupaten Bima merupakan Kabupaten yang kaya spot wisata sehingga masyarakat atau pelaku usaha diharapkan lebih kreatif dalam mengembangkan usahanya serta memiliki kraeatifitas yang tinggi dan kemampuan lain dalam

25 Selamet, Kasi Ekonomi Kreatif Berbasis Seni, Budaya, Media, Desain dan IPTEK, Wawancara langsung di Kantor Dinas Pariwisata Kabupaten Bima 25 Agustus 2020 jam 10:30.

26 Daryanto, Manajemen Pemasaran,...........,95. 
kegiatan usaha yang berkaitan kepariwisataan untuk meningkatkan kesejahteraanya, sehingga pengembangan pada jasa usaha pariwisata terus meningkat dan lebih baik lagi" 27 .

3. Publisitas (publicicity)

Terdiri atas periklanan dan publisitas mass selling merupakan pendekatan yang menggunakan media komunikasi untuk menyampaikan informasi kepada khayalan ramai dalam satu waktu. Informasi tentang kepariwisataan Kabupaten Bima dapat diakses melalui alamat dibawah ini:
a. Email
: dinaspariwisatabimakab@gmail.com
b. Facebook : dinas pariwisata kabupaten bima, dan
c. Instagram : dispar_kabupatenbima. ${ }^{28}$

4. Promosi penjualan (sales promotion)

Alat kegiatan promosi selain periklanan, personal selling dan publisitas ialah berupa sales promotion yang dilakukan dengan peragaan, pertunjukan dan pameran, demonstrasi dan berbagai macam usaha penjualan yang tidak bersifat rutin. Selamet selaku Pembina Ekonomi Kreatif Dinas Pariwisata Kabupaten Bima menyatakan:

"Pada pemasaran langsung Dinas Pariwisata Kabupaten Bima menyelanggarakan event-event setiap tahunya, kemudian dalam acaraacara pemerintah Kabupaten Bima yaitu acara promosi pembangunan Kabupaten Bima yang didalamnya terdapat beberapa anggenda dalam memasarkan produk pariwisata kepada masyarakat maupun wisatawan". 29

5. Pemasaran Sponsorships (Marketing Sponsorships)

Pemasaran Sponsorships adalah aplikasi dalam mempromosikan perusahaan atau lembaga/instansi atau salah satu merek dengan kegiatan tertentu. Sponsorship memiliki kemampuan untuk menyampikan di sejumlah bidang komunikasi. Hal ini dinas pariwisata Kabupaten Bima telah mengupayakan dan membuat merek untuk pariwisata Kabupaten Bima yaitu lambang pesona Dana Mbojo ${ }^{30}$ yaitu perpaduan antara lambang pesona Indonesia dengan lambang Kesultanan Bima yaitu burung Garuda berkepala dua. Merek/brand ini akan menjadi lambang yang dipakai dalam mempromosikan sektor kepariwisataan di Kabupaten Bima.

6. Komunikasi Di Tempat Penjualan (point-purchase-communication)

Bentuk ini melibatkan peraga, poster, tanda, dan berbagai materi lain yang didesain untuk mempengaruhi keputusan untuk membeli dalam tempat pembelian. Komunikasi ditempat pembelian (point-purchase-communication) dalam sektor pariwisata sendiri seperti penyediaan took cinderamata oleh khas daerah. ${ }^{31}$

H. Fatur dalam penyampainya mengatakan bahwa:

“Bidang ekonomi kreatif telah berupaya untuk melakukan pelatihanpelatihan serta mengeluarkan berbagaimacam bantuan peralatan, yang mengarahkan kepada seluruh pemuda kreatif yang bergabung dalam kelompok sadar wisata agar lebih kreatif dan inovatif dalam kegiatan

27 Zulkifli, Wawawancara, selaku kasi pemberdayaan masyarakat bidang pengembangan pariwisata Kabupaten Bima, 12 Oktober 2020

28 Pamfleat Destinasi Wisata Unggulan Kabupaten Bima (Bima Ramah) 2018.

29 Selamet, Selaku Kasi Ekonomi Kreatif Berbasis Seni, Budaya, Media, Desain dan IPTEK (Dinas Pariwisata Kabupaten Bima), Wawancara, Aula Rapat DISPAR Kab. Bima, Kota Bima 10 Mei 2020

30 Keindahan Dana Mbojo (Tanah Bima)

31 Andi Nur Azakiyah, "Strategi Promosi Dinas Kebudayaan Dan Pariwisata Dalam Meningkatkan Kunjungan Wisatawan Di Pantai Tanjung Bira Kecamatan Bontobahari Kabupaten Bulukumba".......,19. 
pembuatan cendramata baik berupa baju kaos, gantungan kunci, tas dan sebagainya untuk menambah nilai pada objek wisata itu sendiri" ${ }^{32}$

\section{Perspektif Ekonomi Syariah Tentang Strategi Promosi Pengembangan Pariwisata yang dilakukan Dinas Pariwisata Kabupaten Bima.}

Prinsip ekonomi Islam yang dipakai yaitu kebenaran dan kejujuran. Dalam ekonomi Islam mempromosikan suatu produk melalui iklan, kebenaran dan kejujuran adalah dasar nilai ekonomi Islam. Islam sangat melarang kebohongan dalam berbagai bentuk. Maka dari itu setiap pengelola harus berlaku jujur, benar dan lurus dalam melakukan promosi sesuai dengan iklan yang ditampilkan. Tidak boleh berlaku curang, berkata bohong bahkan mengumbar sumpah atau iklan palsu. Suatu informasi produk walaupun dengan secara bebas memilih kreasi penyampaianya, tetapi dibatasi oleh pertanggung jawaban secara horizontal dan vertical sekaligus. Suatu kebebasan yang tak terkendali yang membuat suatu pasti tidak akan membawa dampak positif walaupun dalam jangka pendek mungkin menguntungkan.

Demikian pula nilai kebenaran harus dijunjung tinggi untuk mempertahankan suatu tujuan luhur dari bisnis. Kebebasan dalam kreasi penyampainya harus diimbangi dengan pertanggung jawaban manusia. Jadi iklan Islami adalah bentuk komunikasi tidak langsung yang didasari pada informasi mengenai suatu produk yang bertujuan untuk mempengaruhi konsumen dalam penyajianya berdasarkan pada etika periklanan Islami. Pengiklan juga harus menghindari iklan yang menipu dan berlebihan yang dianggap sebagai bentuk kebohongan. Kebenaran fakta dalam informasi yang disampaikan kepada public.

Bapak Taufan selaku kasi informasi dan promosi Dinas Pariwisata Kabupaten Bima menyampaikan:

“Dalam hal memberikan informasi serta berpromosi kami pihak Dinas Pariwisata selalu mengedepankan nilai-nilai kejujuran, baik dalam data informasi yang disebarkan melalui buku-buku maupun dalam media internet." 33

Prinsip ekonomi Islam yang dipakai yaitu keikhlasan. Islam menetapkan keikhlasan sangat penting dalam setiap langkah kehidupan manusia. Berdasarkan hal itu, keikhlasan pelaku bisnis diharapkan tidak berlaku curang ataupun melanggar kepentingan orang lain dengan sengaja. Pada saat prestasi tenaga penjual menguraikan fitur-fitur penting dari produknya, menonjolkan kelebihan kelebihanya dan menyebutkan contoh-contoh kepuasan konsumen. Oleh karena itu pada saat presentasi, tenaga penjual harus dipersiapkan dengan baik, dilatih kembali apa yang mereka katakana, menggunakan kontak mata langsung, bertanya dengan pertanyaan terbuka dan bersikap tenang. Meskipun demikian, dalam mempersentasikan suatu produk diharapkan untuk berbicara jujur dan bisa memenuhi janji-janjinya.

Bapak Dahlan selaku Kepala Dinas Pariwisata Kabupaten Bima menyatakan bahwa:

32 H. Fatuhurrahman, selaku Kasi Fasilitasi Pengembangan Ekonomi Kreatif Dinas Pariwisata Kabupaten Bima, Wawawancara langsung di Kantor Dinas Pariwisata Kabupaten Bima, 04 November 2020 Jam $09: 22$

33 Taufan, selaku Kasi Informasi dan Promosi Pariwisata Kabupaten Bima, Wawancara, di Kantor Dinas Pariwisata Kabupaten Bima 13 Mei 2020 
“Masyarakat Kabupaten Bima adalah mayoritas penganut agama Islam, meskipun begitu wisatawan muslim tidak terbatas hanya pada wisata syariah yaitu wisata religi atau wisata ziarah ulama, mengunjungi masjid-masjid peninggalan sejarah atau yang lainya melainkan seluruh kegiatan pariwisata yang mengikuti nilai-nilai syariah sebagaimana yang terkandung dalam agama Islam itu sendiri".34

Berdasarkan pernyataan diatas bahwa pariwisata syariah bukan hanya wisata ziarah, melainkan sebuah trend baru pariwisata dunia yang dapat berupa wisata alam, wisata budaya, maupun wisata buatan yang keseluruhanya kekayaan potensi wisata alam, budaya, sejarah dan kekhususan yang dimiliki Kabupaten Bima merupakan anugerah Allah SWT, yang mempunyai fungsi dan peranan penting bagi kehidupan dan wilayah Kabupaten Bima.

Dinas Pariwisata Kabupaten Bima juga berusaha untuk selalu memberi kenyamanan untuk para wisatawan dengan memberikan penunjang kegiatan pariwisata salah satunya tempat wisata dilengkapi dengan sarana ibadah untuk wisatawan muslim.

Praktek promosi pariwisata dengan sampel penelitian di Dinas Pariwisata dalam tinjauan ekonomi Islam untuk melihat sudah relevan atau tidak etika promosi pada Dinas Pariwisata Kabupaten Bima bagian dari etika bisnis menunjuk kepada studi tentang aspek-aspek moral dari kegiatan ekonomi dan bisnis. Moral adalah sistem nilai tentang apa yang dianggap baik dan dianggap buruk. Adapun etika yang dilakukan Dinas Pariwisata Kabupaten Bima dalam berpromosi sesui dengan Islam, antara lain:

1. Tidak mengobral sumpah, dalam memberiklan maupun berpromosi

Bersumpah berlebihan dilarang dalam etika promosi Islam, mengobral sumpah tanpa dengan sesuai dengan apa yang sesungguhnya dapat merusak nilai-nilai Islami. Sebagaimana yang diungkapkan oleh Bapak Abdul Haris selaku Kepala Bidang (KABID) Promosi Pariwisata Kabupaten Bima dalam penyampaianya:

"Kami dari tim/bidang promosi pariwisata di Dinas Pariwisata Kabupaten Bima dalam memasarkan ataupun mempromosikan destinasi wisata selalu menjaga nama baik dinas pariwisata. Beberapa brosur dan buku-buku yang kami terbitkan sudah memenuhi standar dan ketentuan yang berlaku yaitu tanpa menutup-nutupi ataupun memberikan informasi palsu. Kami memberikan informasi sesui dengan kondisi objektif". ${ }^{35}$

2. Jujur

Berdasarkan hasil penelitian pada Dinas Pariwisata Kabupaten Bima, selalu bertindak jujur kepada para wisatawan dalam hal beriklan atau memberikan informasi seputar objek wisata atau jasa wisata yang ditawarkan, tidak pernah menipu para wisatawan. Hal ini dapat dibuktikan dari fakta yang ada dengan apa yang telah dipromosikan Dinas Pariwisata Kabupaten Bima baik dalam media cetaknya maupun elektronik. Karena dengan jujur akan menjalankan bisnis dengan tenang, serta mengangkat harta dan martabat

34 Dahlan (Kepala Dinas Pariwisata Kabupaten Bima), Wawancara Langsung di Kantor Dinas Pariwisata Kabupaten Bima 02 April 2020

35 Abdul Haris, selaku Kabid Pemasaran, Wawancara langsung di kantor Dinas Pariwisata Kabupaten Bima, 16 November 2020 jam 11:45 
pariwisata Kabupaten Bima, selain itu dengan jujur akan menghasilkan keuntungan di dunia dan akhirat.

3. Menjaga agar selalu memenuhi akad dan janji serta kesepakatan-kesepakatan di antara kedua belah pihak (pembelian dan penjual)

Hal yang dimaksud iyalah sebagaimana yang diungkapkan oleh Bpak Abdul Haris selaku Kepala Bidang (KABID) Promosi Pariwisata Kabupaten Bima dalam penyampaianya:

"Promosi itu berbiacara tentang sebuah produk yang ditawarkan ke area publik (masyarakat) hal semisal tentang event-event yang menjadi produk andalan pariwisata Kabupaten Bima yang selalu diperioritaskan dan pasti akan diselenggarakan. Hal ini juga tidak terlepas dengan mitra kerja pariwisata yang bergabung dalam samasama menyukseskan acara-acara tersebut."

4. Menghindari promosi palsu yang bertujuan menarik perhatian wisatawan dan mendorongnya untuk berkunjung, berbagai iklan di media elektronik dan cetak, model promosi tersebut banyak yang telah melanggar akhlakul karimah. Berdasarkan hasil penelitian pada Dinas Pariwisata Kabupaten Bima, tidak ditemukan berita ataupun iklan yang menambah ataupun melebih-lebihkan yang bertentangan dengan fakta objektif.

Oleh sebab itu dibidang promosi jasa dan etika pemasaran Islam Dinas Pariwisata Kabupaten Bima mengikuti aturan yang sudah dibuat sebelumnya. Menghindari promosi penjualan yang menggunakan penipuan dan manipulasi. Sebab Dinas Pariwisata Kabupaten Bima juga selalu melihat realita yang ada sehingga wisatawan juga tidak kecewa setelah berkunjung ke Kabupaten Bima karena apa yang telah dipromosikan dengan berbagai media sesuai dengan apa yang ada di lapangan.

Berdasarkan pemaparan diatas mengenai starategi promosi dalam perspektif ekonomi Islam dapat disimpulkan bahwa berdasarkan prinsip ekonomi Islam dalam berpromosi dan etika bisnis Islam yang terdiri dari kejujuran, amanah, keadilan, dan istiqomah. Peinsip ekonomi Islam dalam berpromosi dan etika bisnis Islam tersebut juga diperlukan kekonsistenan untuk diterapkan agar bisnis yang dijalankan sesuai dengan aturan syariah yang berasal dari Allah SWT, sebagaimana yang telah dicontohkan oleh nabi Muhammad SAW.

\section{PEMBAHASAN}

\section{Strategi Promosi Pariwisata Yang Dilakukan Oleh Dinas Parawisata Kabupaten Bima Dalam Meningkatkan kunjungan wisatawan}

Pembahasan ini akan disajikan beberapa uraian pembahasan yang sesui dengan hasil penelitian, sehingga pada uraian pembahasan ini peneliti akan menjelaskan hasil penelitian dengan teori yang sudah dijelaskan pada bab sebelumnya. Data-data diperoleh dari pengamatan wawancara mendalam serta dokumentasi sebagaimana peneliti deskripsikan pada analisis data kualitatif dan kemudian diidentifikasi agar sesui dengan tujuan yang diharapkan. Pengamatan wawancara yang telah dilaksanakan yaitu mengumpulkan data mengenai strategi promosi pengembangan pariwisata dalam perspektif ekonomi syariah pada Dinas Pariwisata.

Dalam wawancara dan observasi peneliti, untuk melihat sejauh mana penerapan teori dan praktek bauran promosi, maka strategi bauran promosi yang 
dilakukan oleh Dinas Pariwisata Kabupaten Bima dalam rangka meningkatkan kunjungan wisatawan adalah sebagai berikut:

1. Periklanan (Advertising) Dinas Pariwisata Kabupaten Bima

Periklanan yang dilakukan oleh Dinas Pariwisata Kabupaten Bima melalui beberapa wawancara dan observasi yaitu melalui media cetak dan media elektronik. Media cetaknya iyalah menerbitkan brosur booklet dan bukubuku tentang pantuan wisata Kabupaten Bima, sedangkan media elektroniknya iyalah dipromosikan melalui internet yang memuat informasi seputar sektor kepariwisataan Kabupaten Bima. Informasi ini bisa melalui Google, Facebok, Instagram dll. Seharusnya periklanan pariwisata juga harus masuk dalam ruangruang terbuka seperti hotel, bandara udara, bank, dll. Sehingga sektor pariwisata Kabupaten Bima lebih jauh dikenali oleh kalangan masyarakat luas.

2. Penjualan perorangan (personal seling)

Yang dilakukan oleh Dinas Pariwisata Kabupaten Bima dalam hal ini merupakan komunikasi langsung tatap muka antara Dinas Pariwisata Kabupaten Bima kepada wisatawan guna membentuk pemahaman yang baik terkait objek wisata yang ditawarkan. Sebagai contoh pada saat diadakan pameran atau event-event yang diselenggarakan atau diikuti oleh Dinas Pariwisata Kabupaten Bima merukan kesempatan untuk berkomunikasi secara langsung. Komunikasi tersebut terjadi ketika pengunjung pameran mendatangi stand pameran dan pegawai yang bertugas dapat menyampaikan atau mempresentasikan obyek wisata yang ada dan menjual barang-barang khas daerah yang diambil dari berbagai kecamatan yang ada di Kabupaten Bima untuk ditawarkan kepada konsumen/calon pembeli. Hal ini juga bisa dilihat pada penjualan paket biro perjalan wisata yang kemudian nanti akan di pandu oleh kelompok sadar wisata yang berpengalaman di bidang pemandu wisatawan.

3. Publisitas (publicicity)

Publisitas merupakan kegiatan promosi yang hampir sama dengan periklanan yaitu melalui media masa tetapi informasi yang di beritakan tidak dalam bentuk iklan tetapi berupa berita.

Dinas pariwisata Kabupaten Bima telah bekerjasama dengan beberapa lembaga untuk mendukung keberlangsungan publikasi ini yaitu menerbitkan buku-buku pantuan wisata kabupaten bima, brosur wisata, dan bekerja sama juga dengan beberapa pers yang akan mengeluarkan berita yang positif guna untuk menarik perhatian masyarakat umum. Hal ini juga dilakukan pemberitaan melalui media internet berupa facebook, instagram dan Email yang telah dibuat oleh Dinas Pariwisata Kabupaten Bima.

Dengan adanya media internet ini masyarakat dapat dengan mudah mengetahui berbagai pariwisata yang terdapat di Kabupaten Bima. Yang dapat diakses pada disparbimak@b.com atau di facebook: dinas pariwisata kabupaten bima, apalagi pada jaman modern seperti sekarang ini yang sangat mudah mengakses internet, oleh sebab itu internet adalah salah satu media yang sangat berperan dalam melakukan kegiatan promosi di Dinas Pariwisata Kabupaten Bima.

4. Pemasaran (Sponsorships) 
Dinas pariwisata Kabupaten Bima telah mengupayakan dan membuat merek untuk pariwisata Kabupaten Bima yaitu lambang pesona Dana Mbojo ${ }^{36}$ yaitu perpaduan antara lambang pesona Indonesia dengan lambang Kesultanan Bima yaitu burung Garuda berkepala dua. Merek/brend ini akan menjadi lambang yang dipakai dalam mempromosikan sektor kepariwisataan di Kabupaten Bima. Paket Sponsorships yang dikemas secara tepat dapat menciptakan atau memperkuat kesadaran akan nama yang tinggi. Sponsor ini juga dibuka untuk instansi-instansi atupun lembaga perusahaan-perusahaan lain seperti Taman Nasional, Bank-bank Rakyat, Dinas Lingkungan Hidup, Kehutan, Kelautan, dll, yang mendukung event-event pariwisata Kabupaten Bima.

\section{Tinjauan Perspektif Ekonomi Syariah Tentang Strategi Promosi Pengembangan Pariwisata yang dilakukan Dinas Pariwisata Kabupaten Bima}

Praktek promosi pariwisata dengan sampel penelitian di Dinas Pariwisata dalam tinjauan ekonomi Islam peneliti, melihat sudah relevan atau tidak etika promosi pada Dinas Pariwisata Kabupaten Bima bagian dari etika bisnis menunjuk kepada studi tentang aspek-aspek moral dari kegiatan ekonomi dan bisnis. Moral adalah sistem nilai tentang apa yang dianggap baik dan dianggap buruk. Adapun etika yang dilakukan Dinas Pariwisata Kabupaten Bima dalam berpromosi sesuai dengan Islam, iyalah tidak mengobral sumpah, jujur, menjaga agar selalu memenuhi akad dan janji serta kesepakatan-kesepakatan di antara kedua belah pihak (pembelian dan penjual), dan menghindari promosi palsu yang bertujuan menarik perhatian wisatawan dan mendorongnya untuk berkunjung, berbagai iklan di media elektronik dan cetak, model promosi tersebut banyak yang telah melanggar akhlakul karimah.

Prinsip yang digunakan Nabi Muhammad SAW, adalah personal selling, iklan, promosi penjualan dan hubungan masyarakat, namun cara-cara yang ditetapkan oleh Nabi Muhammad SAW berbeda dengan promosi yang dilakukan pada saat ini. Cara yang dilakukan Nabi Muhammad SAW tidak terlepas dari nilainilai moralitas. Promosi pada era Nabi belum berkembang seperti sekarang ini, dimana seluruh produsen telah menggunakan alat modern, media internet, televisi, radio dan lain-lain.

\section{KESIMPULAN}

1. Strategi promosi yang dilakukan oleh Dinas Pariwisata Kabupaten Bima menggunakan strategi promotion mix yaitu mencakup: Personal Selling (penjualan perseorangan), Mass Selling (Penjualan Massal), Public Relation (Hubungan Masyarakat), Direct Marketing (Pemasaran Langsung). Hasil yang diperoleh dari penelitian ini yaitu strategi promosi Dinas Pariwisata Kabupaten Bima menggunakan media elektronik dan media cetak. Sehingga wisatawan tidak susah untuk mendapatkan informasi destinasi apa saja yang menarik untuk dikunjungi.

2. Strategi promosi Dinas Pariwisata Kabupaten Bima dalam perspektif ekonomi Islam dapat disimpulkan bahwa berdasarkan prinsip ekonomi Islam dalam berpromosi dan etika bisnis Islam yang terdiri dari tidak mengobral sumpah, jujur, menjaga agar selalu memenuhi akad dan janji, menghindari promosi palsu, Dinas Pariwisata sudah menjalankan prinsip Islam dengan benar sesui

36 Keindahan Dana Mbojo (Tanah Bima) 
dengan syari'at Islam. Oleh karena itu dibidang jasa dan etika pemasaran Islam Dinas Pariwisata Kabupaten Bima mengikuti aturan yang berlaku dalam promosi Islam.

\section{DAFTAR PUSTAKA}

Ahmad Mustag, The Furture Of Economics: An Islamic Perspektif, (Jakarta: Asy Syaamil Press \& Grafika, 2001)

Asyraf Muhammad Dawwabah, Meneladani Keunggulan Bisnis Rasulullah Semarang: PT. Pustaka Rizki Putra, 2006

Ali Hasan, Marketing dan Bnk Syariah, Bogor, Ghalia Indonesia, 2010

Burhan Bungin, Metologi Riset Penelitian Sosial : Format 2 Kuantitaif dan Kualitatatif, (Surabaya, Airlangga Unifersity Press 2005)

Danang Sunyoto, "Dasar-Dasar Manajemen Pemasaran ",Yogyakarta: CAPS, 2012

Daryanto, Manajemen Pemasaran, (Bandung, PT Sarana Tutorial Nuraini Sejahtera, 2011)

Departemen Agama RI, Op, Cit, 576.

Departemen Pendidikan \& kebudayaan, Kamus Besar Bahasa Indonesia, Jakarta: Balai Pustaka, 2012

Dinas Pariwisata Kabupaten Bima, Pariwisata dan Ekonomi Kreatif, Penguatan Industri Pariwisata Daerah Melalui Ekonomi Kreatif,(Bima Maret 2019)

Dinas Pariwisata Kabupaten Bima, Travel Guide To Bima Regency (Panduan Wisata Kabupaten Bima), (Jakarta, ASITA 2018)

Fandi Tjiptono, Strategi Pemasaran, Yogyakarta: Andi, 2008

Gamal Suwantoro, Dasar-Dasar Pariwisata, Yogyakarta: ANDI, 2005

Juhjaya S. Praja, Ekonomi Syariah, (CV. Pustaka Setia, Bandung, 2012)

Juliansyah Noor, Metologi Penelitian, Skripsi, Tesis, Disertasi, \& Kariya Ilmiah, Jakarta,PT Fajar Interpratama Mandiri, 2017

Leiper, Neil, Tourism Management, (Australia: Person Hospitality Press 2004)

Lexy J Moleong, metodologi penelitian kualitatif, (Bandung PT. Remaja Rosdakarya, 1989)

Mustafa Edwin Nasution dkk, Pengenalan Ekslusif Ekonomi Islam, (Jakarta: Kencana, 2007)

Moh Pabundu Tika, Metologi Riset Bisnis, (Jakarta:Bumi Aksara,2006)

M. Mursid, Manajemen Pemasaran, (Jakarta PT Bumi Aksara, 2014)

Nyoman S. Pendit, Ilmu Pariwisata (Sebuah Pengantar Perdana) Cet-8, (Jakarta, Pradnya Paramita, 2006)

Rimsky K. Judisseno, Brending Destinasi dan Promosi Pariwisata (PT Gramedia Pustaka Utama, Jakarta 2019)

Rokhmat Subagiyo, Metodelogi Penelitian Islam: Konsep \& Penerapan, Jakarta: Alim's Publishing, 2007

Rambat Lupiyoadi, A. Hamdani, Manajemen Pemasaran Jasa, Jakarta, Salemba Empat, 2009

Suryadana, M Lingga dan Vani Octavia, Pengantar Pemasaran Pariwisata, (Bandung: Alfabeta 2015)

Warnadi, Aris Triyono, Manajemen Pemasaran, Yogyakarta, CV BUDI UTAMA Mei 2019 
Abdurahman Misno, "Analisi Praktik Pariwisata Syariah Perspektif Hukum Ekonomi Islam", Jurnal Ekonomi dan Bisnis Islam, (Universitas Ibn Khaldum Bogor)

Andi Nur Azakiyah, "Strategi Promosi Dinas Kebudayaan Dan Pariwisata Dalam Meningkatkan Kunjungan Wisatawan Di Pantai Tanjung Bira Kecamatan Bontobahari Kabupaten Bulukumba", ("Skripsi", UIN Alaudin Makassar, 2013)

Is Susanto, Mad Heri, Achmad Fachrudin, "Dampak Strategi Pemasaran terhadap Peningkatan Kesejahteraan Masyarakat dalam Perspektif Ekonomi Islam (Studi Di Pantai Wisata Labuhan Jukung Krui Kab Pesisir Barat)", journal of islamics, finance and banking, No. 1, Volume. 3, Syi'ar Iqtishadi Mei 2019

Mangifera Marsya Nurulwaasi, "Analisis Strategi Promosi Dalam Pengembangan Pariwisata Studi Pada Pariwisata Kabupaten Pesawaran," Skripsi”, Universitas Lampung, Bandar Lampung, 2017

Tiara Apriani Putri Jessy, "Strategi Peningkatan Pendapatan Asli Daerah (PAD)

Kota Balikpapan Melalui Pajak Daerah Sektor Pariwisata", Journal Administrasi Negara, Vol.5 No.3, 1604.

Widiya Agustina, "Analisis Strategi Promosi Dan Pelayanan Pariwisata Guna Meningkatkan Jumlah Pengunjung Di Pantai Sari Ringgung Pesawaran Dalama Perspektif Etika Bisnis Islam "Skripsi”, Bandar Lampung 17 Mei 2018.

Undang-undang Republik Indonesia Nomor 9 Tahun 1990 Tentang Kepariwisataan. Peraturan Bupati Bima Nomor 30 Tahun 2016 Tentang Uraian Tugas, Fungsi Dan Tata Kerja Dinas Daerah Kabupaten Bima

Peraturan Daerah Kabupaten Bima Nomor 4 Tahun 2016 tentang pembentukan dan susunan perangkat Daerah Kabupaten Bima

Pamfleat Destinasi Wisata Unggulan Kabupaten Bima (Bima Ramah) 2018.

UU Pasal 33 Ayat (3) 1945 Tentang Pengelolaan Kekayaan Alam Untuk Kepentingan Rakyat Indonesia

https:/ / www.bimakini.com, 5 September 2019

https://www.samawarea.com. tanggal 13 Februari 2020

https:/ / bulu7labs.blogspot.com/2019/08/ kompilasihukum-ekonomi-syariahprivacy.html.

Sharingkepariwisataan.blongspot.com 